\title{
Writing the Irish past: An investigation into post- primary Irish history textbook emphases and historiography, 1921-69
}

\author{
Colm Mac Gearailt* - Trinity College Dublin, Republic of Ireland
}

\begin{abstract}
This paper maintains a focus on textbooks published and used at post-primary level in the Irish Free State/Republic of Ireland between the 1920s and late 1960s, in the initial decades of the nascent Free State. Viewed by many as the closest way, after direct fieldwork, of finding out the content of teaching, textbooks have also been seen to act as condensed versions of the society that produced them. The textbooks used rarely changed during this period, for a number of reasons, both practical and ideological. Consequently, it can be accepted that a reasonably similar account of the Irish past was transmitted in print to post-primary students across the period.

The article offers an investigation into Irish history textbook historiography, and highlights select examples of how this affected the version of the Irish past being transmitted in print in Irish post-primary schools. It provides the first quantitative analysis and comparison of the central Irish history textbooks in operation during this period. By establishing what textbooks were in use, discussing who they were written by, and then by analysing, cross-comparing and examining their respective emphases, this paper offers an understanding of the general narrative of Irish history as portrayed in secondary schools, from this textual perspective. It focuses predominantly on content inclusion and scope, as opposed to how this content was engaged with. Ultimately, this paper argues that a general narrative of Irish history was maintained across each of the textbooks, which tended to focus on a traditional 'great man' approach to history, with a strong emphasis on high politics. That said, this was not oppressive or rigid, as there was no single consensus view as to what aspects of Irish history were most important within this tradition, with different emphases being placed on various events and figures in Irish history. These differences varied according to the political, class and religious orientation of the author.
\end{abstract}

Keywords: textbooks; Irish history; historiography; post-primary history education; national identity; EIRE

\section{Textbooks and the teaching of Irish History, 1921-69}

In 1945, the Annual Report of the Irish Department of Education (DOE) declared that quality textbooks, in accordance with the standards of the time, were 'perhaps more beneficial in the teaching of history than in the teaching of any other subject' (DOE, 1946: 26; translated from Gaeilge by author). Both at home and abroad, the issue of school textbooks in the history classroom has been, and continues to be, a point of contention. Viewed by many as the closest way, after direct fieldwork, of finding out the content of teaching, history textbooks have also been seen to act as a condensed 
version of the society that produced them (Fischer, 2000: 31). In the Irish context, following the establishment of the Department of Education in 1924, in the immediate post-Independence years, history became a mandatory part of the secondary school Intermediate programme for the first time. Secondary education in the Irish Free State (and later in the Republic of Ireland) consisted of a two-tiered examination system: the Intermediate Certificate Examination, to be taken after four years' study, and the Leaving Certificate, to be taken after two further years. The Department of Education set the syllabus for these examinations, although the individual schools and classes were privately run, predominantly by the Catholic Church. Irish history comprised 50 per cent of the history course, the other 50 per cent being European history. While not mandatory for the Leaving Certificate, history was a very popular choice at this level, owing to the influence that earlier subject study had in shaping subject choice for those who continued on to the higher courses (Guinan, 2001). Of the 3,627 students who sat for the Leaving Certificate in 1943, for example, 3,221 sat for history, or just under 89 per cent of the total (DOE, 1943: 105). The great majority of students who attended secondary school throughout this period studied Irish history. What is more, it was widely acknowledged that history teaching in the Irish Free State and beyond was heavily dependent on the use of textbooks (Milne, 1979: 26; see also DOE, 1946: 26). These were seen not only as an exposition of a particular branch of study, but also (and in certain instances, exclusively) as a programme book for students, containing the course to be taught, and the manner and order in which this was to be done (Mac Niocaill, 1939). It is therefore necessary, in relation to any investigation of how Irish history was taught at post-primary level during this period, to establish which textbooks were used in these schools, who wrote them, what they said, and whether a consistent narrative of the Irish past was being promoted through these texts.

In terms of classifications, the narrative form has been defined by one educational historian as a 'mode of comprehension':

... [a] structure designed to create knowledge about and understanding of the events of the past. A historical narrative does not portray the past itself; it is not a story supported by evidence but the statement of the evidence itself, organised in narrative form. (Vanhulle, 2009: 264)

This paper interprets narrative according to a few select criteria: namely, in relation to the various modes of explanation and the modes of emplotment of each textbook (White, 1973, 1984), or, in other words, by examining the events chosen to be discussed and the order in which they are laid out. It considers the connections made between events and people throughout the textbook/series of textbooks and how these are fitted into a wider arc, before finally considering the descriptions given by the authors of these events and characters.

The three central issues of subject matter, aim and mode of representation are all crucial to understanding the function of a piece of writing (White, 1984: 5), specifically here, the story of the Irish past being presented in history textbooks. That said, this article is not so much an investigation of the narrative of Irish history, and especially the latter issue of modes of representation, as it is a study in historiography and topic emphases.

By establishing first and foremost what textbooks were in use in schools, and hence, by analysing these specific works and comparing them, it is possible to get at the general understanding of Irish history as portrayed in secondary schools, from this textual perspective. While a list of recommended texts existed, there were no officially prescribed set texts when it came to history. Each school, and within a school each 
subject teacher, was free to choose the textbook to be used. The fledgling status of the newly independent Irish state provides an ideal textbook area to analyse. This is owing to the fact that the textbooks used rarely changed. This was for a number of reasons, both practical, in terms of costs, and ideological, in terms of how what was being taught reflected the ethos and beliefs of the wider society and those in positions of power, namely the various church bodies in charge of education. This article will first engage in an analysis of the most popular textbooks by author, before analysing the respective emphases placed in these works on the course of Irish history. Developing from the work of Mariam Chughtai (2015) in Pakistan, it acknowledges the three crucial (though not exhaustive) factors in the Irish context as to why textbooks were chosen: (1) political and class leanings; (2) religious leanings; and (3) affordability.

This paper offers the first comprehensive breakdown of the major textbooks used to teach Irish history at post-primary level between 1921 and 1969, in terms of charting what was being discussed and to what extent. Ultimately it argues that a general narrative of Irish history was maintained across each of the textbooks, which tended to focus on a traditional 'great man' approach to history, with a strong emphasis on high politics. This consistent approach would point to an educational environment in which there was an overall consensus in terms of what the general message of the textbooks should be, in line with the moralistic and cultural 'policy of Gaelicisation' implemented by the Department of Education (Coolahan, 1981: 72-3; Ó Buachalla, 1988, 340-50), but which offered a wide range of choices within that understanding. To this end, this paper will demonstrate how the narrative was not necessarily oppressive or rigid, as there was no single consensus view as to which aspects of Irish history were most important within this tradition, with different emphases being placed on various events and figures in Irish history, and that these differences varied according to the political and class bias of the author. It is also worth noting that, unlike other nation states at this time and now, there was no state-sanctioned textbook in Ireland, reflecting the private nature of the Irish secondary schools themselves.

In order to engage in a comparison of post-primary Irish history textbooks, the paper establishes the central textbooks in use between 1921 and 1969. Due to the lack of archival preservation work done by the Irish publishing houses, a more circuitous method was required in order to ascertain this. Popularity has been gauged according to accounts from the time, and surveys conducted about the time, from newspaper reviews of textbooks and their authors, and finally from noting the (limited) sales figures and repeat editions (which demonstrate that a textbook had sold out, and was considered popular and profitable enough by the private publisher to issue another edition). As will be demonstrated, it emerged that by the mid-1930s, the three textbooks that were most recommended and that were widely used in secondary schools for teaching Irish history were: James Carty's A Class-Book of Irish History Volumes I-IV (Carty, 1929, 1930a, 1930b, 1936), Father John Ryan's History of Ireland Volumes I and II (Ryan, 1929a, 1929b, 1931, 1934), and the more 'advanced book' (Irish Press, 1936), A Short History of the Irish People by Mary Hayden and George A. Moonan (Hayden and Moonan, 1921).

While the first two texts undoubtedly were more popular in terms of sales figures, Hayden and Moonan's A Short History of the Irish People offered the most comprehensive account of Irish history for use in schools, and, unlike the other two titles, was available and was used for the entirety of the period under investigation. In the following decades, two further titles emerged as increasingly popular, Mícheál Ó Siochfhradha's Stair-sheanchas Éireann (Ó Siochfhradha, 1932, 1933) and Dora Casserley's History of Ireland I and II (Casserley, 1941a, 1941 b). 
These five works comprised the standard school textbooks used in the majority of secondary schools in Ireland until the introduction of the massively influential Gill and Macmillan series in the late 1960s. This latter series was seen as the first significant move away from the predominant focus on political and military history, as mentioned earlier, and underpinned 'a long-overdue modernization of the history curriculum' (Larkin, 2012: n.p.).

The language adopted in the Gill and Macmillan texts and thereafter was seen as more temperate, with the series being defined by one writer as consisting of 'moderate' texts, in comparison to the 'purist' texts on Irish history that preceded it. The latter were defined as those that tended to venerate the 'heroes' of Irish history, while the former were more prone to revise many of these earlier assessments (Mulcahy, 1988). The publication of this series marked 'a new era in Irish history school texts' and was seen to set 'a standard in presentation and in format which is radically different from that which preceded it' (ibid.: 7-8). While these works were hugely important in altering how Irish history was taught, in line with the belief that 'the most effective way to change classroom practice is to change the textbooks' (Travers, 1996; see also Milne, 1979: 27), this article focuses on those texts in use during the earlier period, during the initial decades of the independent state. Furthermore, it is important to acknowledge that the texts chosen for analysis were not the sole works that were in use in schools, especially throughout the 1920s.

Other important textbooks on Irish history include those by P.W. Joyce (1924), Mrs Thomas Concannon (1920) and A.M. Sullivan (1867), as well as the respective works of Constantia Maxwell (1914) and H. Kingsmill Moore (1914), which were used in many schools run by the Church of Ireland (see Fischer, 2004). Although it is important that they be recognized, these texts do not constitute the dominant focus of this paper, owing to the fact that their use in secondary schools was largely superseded by the textbooks listed, especially from the early 1930s onwards.

\section{Textbook historiography}

Having outlined which texts were most popular, it is crucial to examine who wrote them. The earliest of the five textbook series named was Hayden and Moonan's A Short History of the Irish People. Published in 1921, in the middle of the Irish War of Independence, A Short History was co-written by barrister-at-law (and later circuit court judge) George A. Moonan, and Mary Hayden, University College Dublin professor of history. Moonan covered the prehistoric era through to the fifteenth century, as well as the brief sections on language and literature, while Hayden wrote the bulk of the textbook from the early Tudors until modern times. Adopting a Catholic nationalist perspective, Hayden presents the story of the Irish Catholics (while allowing some discussion of Protestant patriots and nationalists from the eighteenth century onwards), by focusing on the moments of political and military conflict, from the Tudor period until modern times. Her work was lauded for avoiding many of the weaknesses of previous nationalist historians - namely for not adopting a simplistic 'Whig-nationalist' conceptual framework when analysing the various uprisings in Ireland (Smith, 2006: 11) - as well as for its treatment of religion (O'Conor, 1923: book review section, 2).

Created initially as a textbook for university students, 'Hayden and Moonan', as the text became known, acknowledged in its preface that:

While written from a frankly national stand-point, the authors have made every effort to attain accuracy and avoid prejudice. Events are dealt with, as far as possible, in the spirit and atmosphere of their times, but are 
judged by their final effects upon the destinies of the nation. (Hayden and Moonan, 1921: iii)

It aimed to show Ireland's history not as a series of unconnected events, but as a sequence. Like its note on Irish literature, Irish history - as taught in secondary schools - was to be seen as 'the product, not of an isolated age or period, but of successive generations from the remote past down to the present day' (ibid.).

Although comprehensive, Hayden and Moonan's work was by no means ubiquitous. By far the most popular textbook series in use in secondary schools from the beginning of the 1930s until the late 1960s was written by James Carty. His A Class-Book of Irish History Volumes I-IV were repeatedly stressed in contemporary newspapers to be the 'best introduction to Irish history extant' (Irish Press, 1939: 8; also 1941: 2). James Carty MA, a librarian with the National Library of Ireland, had previously been employed by Dáil Éireann in 1921, before being expelled for supporting those who were against the Anglo-Irish Treaty. A prominent journalist as well, Carty featured regularly in the Irish Times and the Irish Press. Praised for a general sense of balance and judiciousness (Ferriter, 2015: 46; also Boylan, n.d.; Carty, 1948: 3), his textbooks were immediately popular (as noted in the Irish Press on 14 December 1931), with contemporary reviews declaring them 'an indispensable working-tool for all those who teach the history of Ireland' (Irish Times, 1937). The Class-Books were in constant production during the four decades after their original publication. Book IV, for example, originally published in 1931, was reprinted three times in the following five years alone, in 1932, 1934 and 1936, and then again in 1940, 1942 and 1943. New editions of the Class-Books were published in 1945 (hardback), 1946 (Volumes I and II), 1948 (Volumes III and IV) and 1951 (Volume I), while a further edition was published in 1965. This popularity is also highlighted by the promptness with which Carty's text was recommended for translation by the Department of Education's Publication Branch, An Gúm, who 'considered that an Irish translation of this book is badly needed for the purposes of the teaching of history' (MacLellan, 1935).

As for other textbooks, among the few texts for which sales figures do exist are the translations of the two-volume series on the History of Ireland - Ireland from the Earliest Times to A.D. 800 and Ireland from A.D. 800 to A.D. 1600 - by Father John Ryan SJ, professor of medieval Irish history at University College Dublin. Originally published in 1929, and commended by his academic peers for their quality, Ryan's textbooks were also immediately successful among a more popular audience (Irish Press, 1936). As a later review of the translations, referring to the originals, further demonstrated:

The school text itself is a model for what a history primer ought to be. It is based soundly upon the latest researches of contemporary scholars. Legend and rhetoric are subordinated to the ascertained facts of history, and for once, guess work is replaced by reasoned argument on doubtful points. (Irish Times, 1931: 3)

By the start of the 1940s, Father Ryan's Stair na hÉireann Volume I had sold 5,934 copies in total (Doherty, 1994: 25). When it is remembered that these were the sales figures for the Irish translation only, and that the English text was both widely available and recommended, the popularity of Ryan's work as a school textbook throughout the 1930s and early 1940s can safely be assumed.

Published in the same year as Carty, the two were often discussed together in contemporary accounts of Irish history in schools (Irish Times, 1931: 3). Ryan's texts were more advanced than Carty's, catering more specifically for the secondary school 
market, whereas Carty, as acknowledged on the sleeve of each text, was aimed at both primary and secondary school students.

Cultural and religious factors were also hugely important when it came to popularity, as highlighted by Mícheál O Siochfhradha's Stair-sheanchas Éireann, Cuid I agus II, and Dora Casserley's History of Ireland. Mícheál Ó Siochfhradha MA was a trained primary school teacher, a professor at Coláiste Caoimhín Preparatory School Glasnevin, Dublin (Irish Independent, 1928), and later worked as a primary and (from 1935 onwards) secondary school inspector with the Department of Education, before becoming Chief Inspector in 1965 - the same year that a new edition of his textbook was published. He was also an important figure in the Irish Language movement, alongside his brother Pádraig Ó Siochfhradha (better known by his pen-name 'An Seabhac'), and was an active member with An Coiste Téarmaíochta, tasked with ensuring that educators through the medium of Irish were provided with comprehensive and accurate terminology in all subjects.

Stair-sheanchas Éireann, Cuid I agus II was the first full textbook series in Gaeilge that dealt with the whole course of Irish history in secondary schools, from 'The Pagan Era' to the War of Independence. This was especially important in line with the growing number of secondary schools where the general curriculum (and history in particular) was being taught through the medium of Irish. In 1922/3, there were 275 secondary schools in operation in the Irish Free State, with 20,600 students enrolled. By 1941/2, this figure had increased to 362 secondary schools on the department's registered list. Of these, 215 were either Class A or Class B schools, with 102 schools in which all instruction was through Irish (Class A) and 113 in which some instruction (other than the subject of Irish) was done through the medium of the lrish language (Class B) (Derrig, 1943). By 1942, it was calculated that there were 25,374 students, or around 64 per cent of the total number of students enrolled in secondary schools, attending either a Class A or a Class B school (DOE, 1943: 21-2; 1943 in ASTI, 1942-74; Derrig, 1943).

The need for textbooks in Gaeilgefor these students was self-evident. Furthermore, the connection between $O$ Siochfhradha's text and the Christian Brothers was widely known, as it was the central textbook for use in schools run by that order throughout the period (Ó Siochfhradha, 2005), and continued to be used even into the 1980s in certain schools (D.Ó hAiniféin, personal communication, 2014). ${ }^{1}$ Although more modest than the high-fee elite Catholic colleges in terms of costs, curriculum choice and facilities, the Christian Brothers, who catered exclusively to the education of boys, were the largest educators in the country (O'Neill, 2014: 63; also Duffy, 1967), thus granting additional weight to $O$ Siochfhradha's text, in terms of its content and its audience.

Finally, following a number of complaints that the standard textbooks on Irish history were promoting an understanding of national identity with which they disagreed (for example, in the Irish Times on 20 May 1939; see also Akenson, 1975: 194), the task of providing a suitable textbook for members of the minority Protestant denominations was seemingly addressed in 1941, with the publication of Dora Casserley's History of Ireland. This was published on receipt of a prize granted by the General Synod of the Church of Ireland. Casserley was a teacher in Alexandra College, Dublin, a member of the Royal Society of Antiquaries of Ireland (Royal Society of Antiquaries of Ireland, 1932: 129) and a prominent member of the Irish Union of Assistant Mistresses (and from the mid-1940s, part of the Association of Secondary Teachers of Ireland History Sub-Committee) (ASTI, 1946, 1947, 1949: 22-4). Her textbook was extremely popular. Originally published as one volume, it was re-issued in 1943 by the Educational Company of Ireland in two parts, Part 1 up to 1603 and Part 2 'From the Flight of the Earls to the Present Day'. By 1947, it had sold over 26,000 copies, and was used 
widely in Protestant schools (both primary and secondary) (Relihan, 2014: 161). It was republished in 1962. It is interesting to note, however, that Casserley's overall account of Irish history differed little from that seen in the other texts, apart perhaps from a greater emphasis in parts on historical movements and events especially relevant to the Church of Ireland and Protestantism in general.

That said, the popularity of textbooks was not solely due to the acceptance of the academic quality of the text, but was also largely influenced by affordability. Whereas the original print of Hayden and Moonan sold for 20/- each in 1921, Carty's ClassBooks sold for 1/- each. Mícheál Breathnach's translation of Ryan, Volume I sold for 2/6, while Volume II (Ireland from A.D. 800 to A.D. 1600) sold for 3/- (An Gúm, 1953). Before the widespread availability of Ryan's and Carty's work, it was readily acknowledged in the Irish Parliament that 'the prices of school books are absolutely out of all proportion to the capacity of many parents in the country to pay', and even more so if the additional hidden costs of education were factored in (Dáil Éireann, 1929). When one considers that Irish history was but one half of one subject in the school curriculum, and that textbooks would be required for all, the 20/- price of Hayden and Moonan would inevitably have resulted in it being inaccessible for a significant proportion of those attending secondary level, which helps explain the continued popularity of the cheaper, coarser paperbacks.

\section{Methodology and textbook emphasis}

To understand the narrative that is being propounded in a history textbook, it is crucial to examine the emphases placed upon specific events, personalities and periods in the past. By cross-comparing the indexes from the different textbooks, it was possible to see not only what elements of Irish history were stressed consistently, but also the noticeable differences in terms of the weighting that different authors gave to specific aspects of Irish history. These differences, it is argued, reflect the different political beliefs and contextual considerations of each writer. It is important to note how the levels of sophistication varied across the textbooks, with some being shorter and simpler owing to their intended audiences.

However, by examining the extent to which certain events or personalities are engaged with, in proportion to the overall work, it is possible to understand what aspects of Irish history were dealt with in more, or in less, depth, in line with issues of emplotment. From this, the areas most emphasized can be clearly and systematically established. In terms of methodology, by dividing the number of pages on which a topic was discussed by the total number of pages in each textbook/textbook series and multiplying by 100 , the percentage of each book dedicated to any given episode, topic or personality could be determined. From this, it was possible to demonstrate the varying emphases of each author, and compare them to see if there were any significant differences in the general accounts given of Irish history. As an illustrative example, Hayden spent 3.4 per cent (or 19 pages of her total work) discussing the period between the Ulster Plantation and the 1641 Rebellion, a period barely touched on in the other works. This is not included in the calculations for direct comparison, as it was not discussed by all.

For the most part, a similar presentation of events could be seen in Carty, Casserley and Ó Siochfhradha, all of which were geared specifically towards a younger audience. Hayden and Moonan, however, seeing as the text was initially intended for university students, did not follow the same shorter and simpler approach seen in the other textbooks, being more comprehensive and content heavy. That said, in terms 
of findings, what is perhaps most noticeable was the textbooks' remarkable similarity to one another, in terms of general narrative and content structure (see Appendix I). In total, the textbooks maintained a high level of consistency in terms of the content addressed, as underlined in the comparison of subject content in Table 1.

Table 1: Degree of consistency in topic engagement across all textbooks

\begin{tabular}{|c|c|c|c|}
\hline Textbook & $\begin{array}{c}\text { Consistency of topic } \\
\text { engagement (\%) }\end{array}$ & Total pages in text & $\begin{array}{l}\text { Pages by } \\
\text { volume }\end{array}$ \\
\hline Hayden and Moonan & 77.44 & 559 & - \\
\hline Carty & 68.25 & 674 & $\begin{array}{l}\text { CB1: } 168 \\
\text { CB2: } 173 \\
\text { CB3: } 164 \\
\text { CB4: } 169\end{array}$ \\
\hline Ó Siochfhradha & 82.12 & 308 & $\begin{array}{l}\text { Cuid 1: } 133 \\
\text { Cuid 2: } 175\end{array}$ \\
\hline Casserley & 86.29 & 314 & $\begin{array}{l}\text { Part 1: } 164 \\
\text { Part 2: } 150\end{array}$ \\
\hline Ryan & $73.75^{\star}$ & 419 & $\begin{array}{l}\text { Vol. 1: } 167 \\
\text { Vol. 2: } 252\end{array}$ \\
\hline
\end{tabular}

* Ryan only covers the period up until 1600, so the degree of consistency has been gauged up until that point for his works.

If we again take Hayden and Moonan as an example, these figures demonstrate that over three-quarters of the textbook discussed matters that were also discussed in all of the other works (excluding post-1600 for Ryan). As historian Herbert Butterfield (1931: 5-6) noted about the same phenomenon, with regard to English history writing:

... this ... tendency is so deep-rooted that even when ... research has corrected the story in detail, we are slow in re-valuing the whole and reorganizing the broad outlines of the theme in the light of these discoveries ... We cling to a certain organization of historical knowledge which amounts to a whig interpretation of history ...

This comparison is specific to subject topic. It is distinct from the actual discussion and perspective taken as to these topics, which differed according to the respective size, scope, and general outlook of each textbook.

Despite the similarity in terms of general content, a very noticeable difference in emphasis can be seen between individual texts. Hayden's political leanings in favour of constitutional nationalism can be detected at times in her work, and are clearly demonstrated in Appendix I, with Henry Grattan, and Charles Stewart Parnell and the Irish Parliamentary Party stressed more than in the other texts, for example. The same can be said for Carty's and Ó Siochfhradha's republicanism and their conceptualization of the dominant motifs in Irish history. Both gave greater attention to the more militaristic aspects of Irish history, and to the frequently militant struggle for land reform. The differences in perspectives are also noticeable in the specific categorization of topics. While Casserley divides the Parnell period along two lines - the Land Question, and the Home Rule Question - Carty groups the whole period under the heading 'The Struggle for Land' (as does Ó Siochfhradha), and thus downplays the importance of the constitutional nationalist dimension in favour of the Land War. In total, Carty dedicated 3.12 per cent (21 pages) to the Land Question, whereas Hayden and Moonan dedicated only 1.79 per cent (10 pages), and Casserley even less 
(0.96 per cent, or 3 pages, of her total). Ó Siochfhradha gave the greatest attention to land agitation among all the authors considered. In contrast, he downplayed parliamentary actions and the attempts for Home Rule, which comprise only 0.64 per cent of his total (less than 2 pages). Hayden, on the other hand, dedicated twice as much discussion to Parnell's political career than to his work with the Land League and Davitt, spending 3.58 per cent of her work (20 pages) discussing the matter.

It is important to acknowledge, however, that in terms of portrayals across texts, despite these differences in detail, the importance of the 'great man' approach to history writing was propounded in all of the textbooks. This is exemplified by Carty in his discussion of Irish literature: 'A nation will not be respected or admired if it is without men of genius. It must not merely produce such men, but it must honour and reward them' (Carty, 1936: 161). Quoting Charles Gavan Duffy's work Young Ireland, Carty went further while discussing the nineteenth and early twentieth centuries, stating the need to honour those literary and artistic figures who 'made Ireland their home, whatever might be their political opinions, for great men make a great nation' (ibid.). By his own admission, his works emphasized '[i]n general the periods of our history which are most inspiring and better calculated to lead to pride of country', and the narrative was 'largely written around the careers of great personalities' (Carty, 1930a: ii-iii). This is qualified by stating that Irish history was not just a dull chronicle of battles and slaughters. That said, this does not negate the high-politics approach, centred on the history of great men who were perceived as central to the political developments of their time (ibid.). Hayden organized specific events around the figures involved, perhaps most tellingly, the way in which the Nine Years' War of the late sixteenth century was termed 'The War of O'Neill and O'Donnell'. It is important to acknowledge that this was not unique to Ireland. As noted by David Sylvester (1994), originator of the Schools Council History Project in England, the high-politics approach seen in these textbooks and the memorization by students of these facts about great men and political events constituted a dominant tradition of how history was taught up until the 1960s, and was specifically cited in contrast to the (gradual) emergence of the 'new tradition' from the late 1960s onwards, both in Ireland and abroad. This international comparison is an area worthy of further research and consideration.

\section{Conclusion}

The Irish history textbooks in use between 1921 and 1969 ultimately aligned with the traditional understanding of what national history entailed, being seen to promote in no uncertain terms political and military history, and focusing on the 'great men' of history. While the central themes of national resistance, unity and religion were evident in all, they did not necessarily engage with them in the same way: there were a variety of differences in emphasis and description. These differences in how the national story was presented were contingent on the textbook historiography, namely the political, religious and class leanings of the authors. But while they may have differed in presentation, and in balance and consideration, the overall narrative that was being transmitted fundamentally stayed the same, with the texts adhering to a 'traditional' rubric. This, along with the approval of these textbooks as demonstrated by their continued use, shows that overall, the texts mirrored rather than challenged the popular perception of Irish history, although the difference in accounts between authors highlights how this public perception was never an entirely homogeneous one. The 'great man' approach to history writing lends itself to a nationalist teleology. Through this, these textbooks could be seen to comply with the theoretical concept 
of cultural hegemony, through the creation of an overall world-view (or, in this case, a historical narrative) that reflected the values of those in power, who were supported by the textbook writers in a way that appealed to the majority of those within society (see Lears, 1985). That Irish history as taught in schools reflected many of the values of the wider society is in keeping with findings internationally (Zúñiga et al., 2015: 8, 42).

Furthermore, that these textbooks were significant in the promotion of a specific understanding of national identity is important in relation to recent international tensions regarding the manipulation of textbook content for political purposes (Guardian, 2014). Issues surrounding what to include, how to frame historical texts, and the extent to which school history should be used to further positive concepts of citizenship and cultural identity are all still important issues in the twenty-first century (Haydn, 2012). By engaging with this earlier period, it is possible to gain an appreciation for how things were promoted within a different cultural context, mirroring David Lowenthal's (1985) credo that the past is a foreign country. Furthermore, this article makes a potentially significant contribution, being the first study of the major textbooks on Irish history in operation during the period under investigation. This shortfall is significant considering the current debate over junior-cycle reform, with a new specification for junior-cycle history to be announced in September 2018 by the National Council for Curriculum Assessment (NCCA) in Ireland, as well as its removal as a mandatory subject for study in voluntary secondary schools. With Irish history so often at the forefront of national politics, as well as public discourse, as part of the Irish Decade of Centenaries - a national initiative dedicated to the programme of commemorations relating to the significant events in Irish history between 1912 and 1922/3 in the lead-up to Irish Independence from Britain - such a study is not only timely, but necessary. In order to make reasoned decisions as to subject value and merit, it is necessary to come from an informed position. As argued by David Cannadine et al. (2011: 17), 'no government should try to "reform" history teaching ... without some awareness of what has gone before, and of how things got to be the way they now are'. Any reform in programmes would in turn require a reform in textbooks. It is important, then, to know how Irish history has been portrayed in the past. What is more, the very difference of such a previous context from our own, and the textbooks in operation at the time, demands that a wary and considered approach be taken by the historian/educationalist with regard to a comparison with modern times (Barton, 2012). This appreciation can help when examining other cultural contexts, which in turn could allow for further international and transnational comparative research to prevail in the field of history education and textbook research.

\section{Notes on the contributor}

Colm Mac Gearailt is currently in the final stages of his PhD at Trinity College Dublin, Ireland, co-supervised between the School of Histories and Humanities and the School of Education. His thesis, for which he was awarded an Irish Research Council Government of Ireland Postgraduate Scholarship in 2017, looks at the teaching of Irish history in secondary schools between 1924 and 1969. His research interests are in history education, cultural memory and identity, and textbook analysis and historiography.

\section{Note}

\footnotetext{
1 At time of interview (12 December 2014), Ó hAiniféin was chairperson of the Gaelscoileanna organization, member of the National Advisory Committee for Education, having worked as a primary school principal. He attended Meanscoil na mBráithre Críostaí, Dingle, Co. Kerry, from 1980 to 1985.
} 







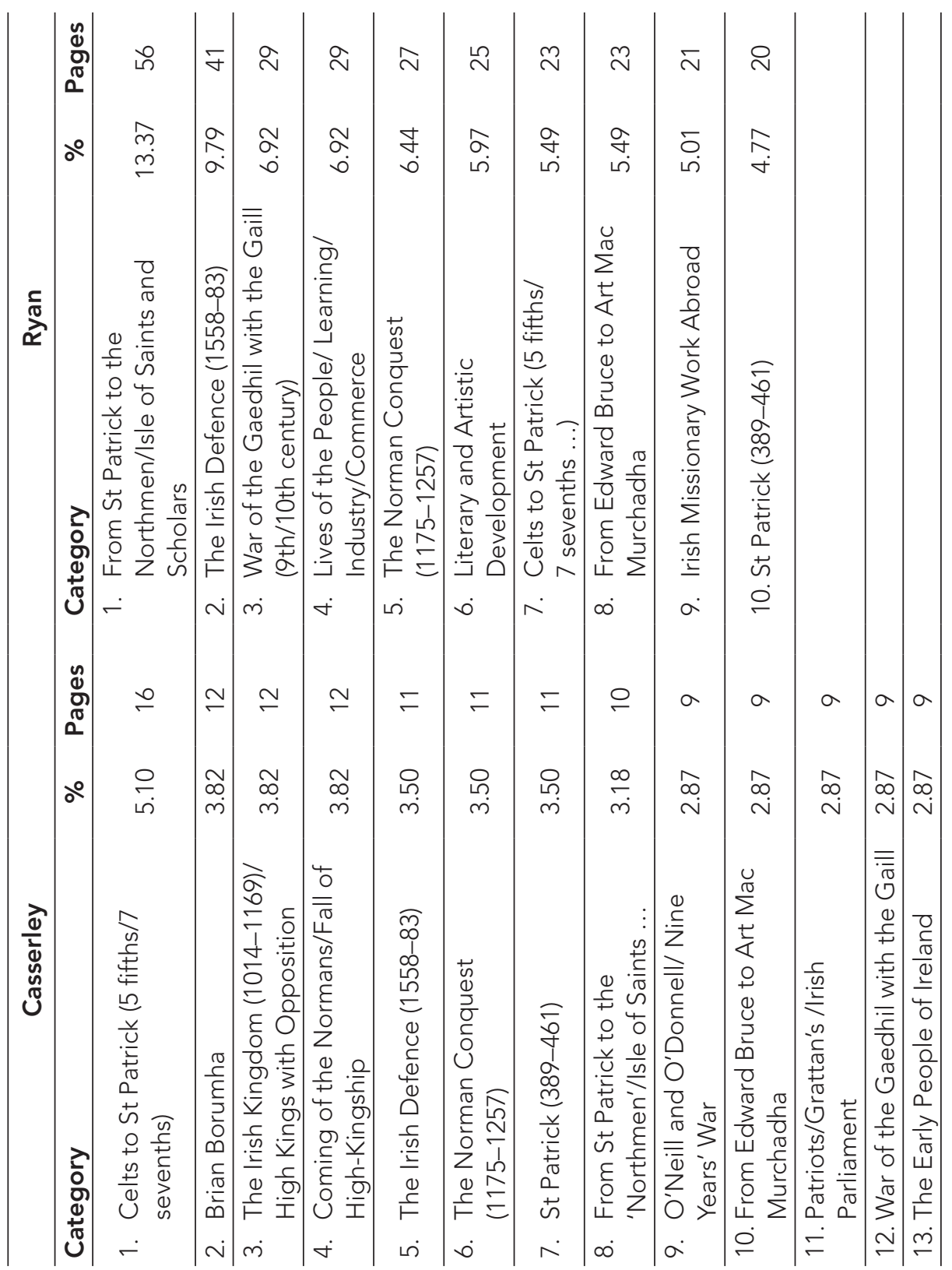




\section{References}

Akenson, D.H. (1975) A Mirror to Kathleen's Face: Education in independent Ireland, 1922-1960. Montreal: McGill-Queen's University Press.

An Gúm (1953) 'Téacsleabhar Mheanscoile, 1938-62' Liosta: Téacsleabhra Meáns-Scol (foilsithe) [Stair],' N.A.I./GAEL/An Gúm/G072.

ASTI (Association of Secondary Teachers of Ireland) (1942-74) 'Annual Convention Minute Books, 1942-74', ASTI/97/48.

ASTI (Association of Secondary Teachers of Ireland) (1946) 'Meeting of the History Sub-Committee', Official Programme of the Annual Convention.

ASTI (Association of Secondary Teachers of Ireland) (1947) 'Meeting of the History Sub-Committee', Official Programme of the Annual Convention.

ASTI (Association of Secondary Teachers of Ireland) (1949) C.E.C. Report, Official Programme.

Barton, K.C. (2012) 'Wars and rumors of war: The rhetoric and reality of history education in the United States'. In Taylor, T. and Guyver, R. (eds) History Wars and the Classroom: Global perspectives. Charlotte, NC: Information Age Publishing, 187-202.

Boylan, C. (n.d.) National Collection of Children's Books (NCCB) project. Online. https://nccb.tcd.ie/ exhibit/3197xm07c (accessed 12 July 2016).

Butterfield, H. (1931) The Whig Interpretation of History. London: G. Bell and Sons.

Cannadine, D., Keating, J. and Sheldon, N. (2011) The Right Kind of History: Teaching the past in twentieth-century England. Basingstoke: Palgrave Macmillan.

Carty, J. (1929) A Class-Book of Irish History: Book I: From the earliest times to the Norman Invasion (1169). London: Macmillan and Co.

Carty, J. (1930a) A Class-Book of Irish History: Book Il: From the Norman Invasion to the Flight of the Earls (1607). London: Macmillan and Co.

Carty, J. (1930b) A Class-Book of Irish History: Book III: From the Flight of the Earls to the Act of Union (1800). London: Macmillan and Co.

Carty, J. (1936) A Class-Book of Irish history: Book IV: From the Act of Union to the present day. 4th ed. London: Macmillan and Co.

Carty, J. (1948) A Junior History of Ireland: Part II: From the Flight of the Earls. London: Macmillan and Co.

Casserley, D. (1941a) History of Ireland: Part I: Earliest times to Flight of the Earls. Dublin: Educational Company of Ireland.

Casserley, D. (1941b) History of Ireland: Part II: From the Flight of the Earls to the present day. Dublin: Educational Company of Ireland.

Chughtai, M. (2015) 'What Produces a History Textbook?'. Unpublished EdD thesis, Harvard University.

Concannon, H. (1920) Irish History for Junior Grade Classes: The defence of our Gaelic civilisation, 1460-1660. Dublin: Fallon Brothers.

Coolahan, J. (1981) Irish Education: Its history and structure. Dublin: Institute of Public Administration.

Dáil Éireann (1929), Debates, 6th Dáil, Vol. 29, No. 4, Cols. 414-5. Online. www.oireachtas.ie/en/ debates/debate/dail/1929-04-17/ (accessed 17 July 2018).

DOE (Department of Education) (1943) An Roinn Oideachais Tuarasgabháil, 1941-42/Report of the Department of Education, 1941-42. Online. www.education.ie/en/Publications/Statistics/ Statistical-Report-1941-1942.pdf (accessed 3 August 2018).

DOE (Department of Education) (1946) An Roinn Oideachais Tuarasgabháil, 1944-45/Report of the Department of Education, 1944-45. Online. www.education.ie/en/Publications/Statistics/stats statistical_report_1944_1945.pdf (accessed 3 August 2018).

Derrig, T. (1943) Speech delivered at 21st ASTI Annual Convention. Annual Convention Minute Books, 1942-74, 27 April 1943, ASTI/97/48.

Doherty, G. (1994) 'The Irish history textbook, 1900-1960: Problems and development'. Oideas, 42, 5-25.

Duffy, P.S. (1967) The Lay Teacher: A study of the position of the lay teacher in an Irish Catholic environment. Dublin: Fallons.

Ferriter, D. (2015) A Nation and Not a Rabble: The Irish Revolution, 1913-1923. London: Profile Books.

Fischer, K. (2000) 'L'histoire irlandaise à l'école en Irlande, 1921-1996'. Unpublished PhD thesis, Université de Caen. 
Fischer, K. (2004) 'Another Irish nation: Some historiographical variations as found in late nineteenth-century and early twentieth-century schools'. Canadian Journal of Irish Studies, 30 (1), 41-7.

Guardian (2014) 'Hundreds of Colorado students stage protest over history curriculum'. 24 September. Online. www.theguardian.com/world/2014/sep/24/denver-students-walkoutprotest-history-school-board (accessed 14 July 2018).

Guinan, A.M. (2001) 'Who, What and Why... Subject Choices for Senior Cycle in a Second Level School'. Unpublished MEd thesis, National University of Ireland, Maynooth.

Hayden, M. and Moonan, G.A. (1921) A Short History of the Irish People. Dublin: Talbot Press. Haydn, T. (2012) 'History in schools and the problem of "the nation"'. Education Sciences, 2, 276-89.

Irish Independent (1928) 'New school inspectors: Appointments in the Saorstát'. 13 September. Irish Press (1931), 14 December.

Irish Press (1936), 15 April.

Irish Press (1939) 'My favourite history'. 25 April, 8.

Irish Press (1941) 'Other notices: Bibliography of Irish history'. 10 June, 2.

Irish Times (1931) 'Irish history in Irish'. 18 September, 3.

Irish Times (1937) 'European History'. 13 March.

Irish Times (1939) 'Teaching through Irish: Synod asks for inquiry'. 20 May, 8.

Joyce, P.W. (1924) A Short History of Gaelic Ireland from the Earliest Times to 1608. Dublin: Educational Company of Ireland.

Kingsmill Moore, H. (1914) Irish History for Young Readers. London: Macmillan and Co.

Larkin, F. (2012) '“A happy monk" Mark Tierney OSB: An appreciation'. History Ireland, 20 (2). Online. www.historyireland.com/20th-century-contemporary-history/a-happy-monk-mark-tierneyosb-an-appreciation-by-felix-larkin/ (accessed 3 January 2016).

Lears, T.J.J. (1985) 'The concept of cultural hegemony: Problems and possibilities'. American Historical Review, 90 (3), 567-93.

Lowenthal, D. (1985) The Past is a Foreign Country. Cambridge: Cambridge University Press.

MacLellan, S. (1935) 'James Carty', 6 March, National Archives of Ireland/GAEL/An Gúm/A 0356.

Mac Niocaill, S. (1939) 'What is a "Text-book"?', 7 February, National Archives of Ireland/GAEL/An Gúm/G072; 'Téacsleabhar Mheánscoile, 1938-62'.

Maxwell, C. (1914) A Short History of Ireland. Dublin: Educational Company of Ireland.

Milne, K. (1979) New Approaches to the Teaching of Irish History. London: Historical Association.

Mulcahy, B.J. (1988) 'A Study of the Relationship between Ireland and England as Portrayed in Irish Post-Primary School History Text Books, Published since 1922, and Dealing with the Period 1800 to the Present'. Unpublished PhD thesis, University of Hull.

O'Conor, N.J. (1923) 'Modern Irish view of Irish history: A Short History of the Irish People'. New York Times, 7 January, book review section, 2.

Ó Buachalla, S. (1988) Education Policy in Twentieth Century Ireland. Dublin: Wolfhound Press.

O'Neill, C. (2014) Catholics of Consequence: Transnational education, social mobility, and the Irish Catholic elite, 1850-1900. Oxford: Oxford University Press.

Ó Siochfhradha, M. (1932) Stair-sheanchas Éireann: Cuid l, ó thús aimsire go 1609 A.D. Baile Átha Cliath: Comhlucht Oideachais na hÉireann.

Ó Siochfhradha, M. (1933) Stair-sheanchas Éireann: Cuid II, ó 1609 go 1933 A.D. Baile Átha Cliath: Comhlucht Oideachais na hÉireann.

Ó Siochfhradha, M. (2005) Stair-sheanchas Éireann: Narrative History of Ireland, Cork, Aubune Historical Society.

Relihan, M. (2014) 'The Church of Ireland, the state and education in Irish language and Irish history, 1920s-1950s'. In Raftery, D. and Fischer, K. (eds) Educating Ireland: Schooling and social change, 1700-2000. Sallins: Irish Academic Press, 147-72.

Royal Society of Antiquaries of Ireland (1932) 'Proceedings'. Journal of the Royal Society of Antiquaries of Ireland, 2 (1), 125-34.

Ryan, J. (1929a) Ireland from the Earliest Times to A.D. 800. Dublin: Browne and Nolan.

Ryan, J. (1929b) Ireland from A.D. 800 to A.D. 1600. Dublin: Browne and Nolan.

Ryan, J. (1931) Stair na hÉireann ó thosach anuas go dtí 800 A.D.: "Ireland from the earliest times to 800 A.D.": Ins an mBéarla bunaidh. Baile Átha Cliath: Muinntir Brún agus Ó Nualláin, Teor., i gcomhar le hOifig an tSoláthair. 
Ryan, J. (1934) Stair na hÉireann ó 800 A.D. go dtí 1600: "Ireland from A.D. 800 to A.D. 1600": Ins an mBéarla bunaidh. Baile Átha Cliath: Muintir Brún agus Ó Nualláin, Teor., i gcomhar le hOifig an tSoláthair.

Smith, N.C. (2006) A 'Manly Study'? Irish women historians, 1868-1949. Basingstoke: Palgrave Macmillan.

Sullivan, A.M. (1867) The Story of Ireland; a narrative of Irish history, from the earliest ages to the present time; written for the youth of Ireland. Dublin: T.D. Sullivan.

Sylvester, D. (1994) 'Change and continuity in history teaching 1900-93'. In Bourdillon, H. (ed.) Teaching History. London: Routledge, 9-23.

Travers, P. (1996) 'History in primary school: A future for our past?'. History Ireland, 4 (3). Online. www.historyireland.com/20th-century-contemporary-history/history-in-primary-school-a-futurefor-our-past/ (accessed 14 July 2018).

Vanhulle, B. (2009) 'The path of history: Narrative analysis of history textbooks - a case study of Belgian history textbooks (1945-2004)'. History of Education, 38 (2), 263-82.

Walsh, P. (2011) 'The political economy of Irish school books'. In Hutton, C. and Walsh, P. (eds) The Oxford History of the Irish Book: Volume V: The Irish book in English, 1891-2000. Oxford: Oxford University Press, 335-66.

White, H. (1973) 'Interpretation in history'. New Literary History, 4 (2), 281-314.

White, H. (1984) 'The question of narrative in contemporary historical theory'. History and Theory, $23(1), 1-33$

Zúñiga, C.G., O’Donoghue, T. and Clarke, S. (2015) A Study of the Secondary School History Curriculum in Chile from Colonial Times to the Present. Rotterdam: Sense Publishers. 